\title{
The Oil Spill Incident in Vietnam
}

\author{
Phuoc Quy Phong Nguyen
}

\begin{abstract}
At present, oil spills are a potential threat to coastal states. In many sea areas of the sea, the phenomenon of "black tide" is common. There are many causes for this situation such as collisions, accidents of water transport vehicles (especially oil tankers), oilrig incident, oil spill incident due to geological changes, waste oil burglary on the sea. For Vietnam, about 200 million tons of oil are transported each year through the sea. In the process of transporting and exploiting offshore, there may be incidents leading to oil spills into the sea, polluting the marine environment. According to statistics, in the past 20 years, about 10 oil spills have been recorded annually, especially in 2012, there were 12 cases affecting the estuarine and coastal environment of Vietnam and coastal ecosystems as well as coastal resorts. This article presents a report on oil spills occurring in Vietnam and policies of the Vietnamese government to respond to oil spills.
\end{abstract}

Index Terms-Oil Spill; Oil Slick; Policy; Vietnam Maritime

\section{INTRODUCTION}

Vietnam is a sea nation, with about one million square kilometers of sea surface, where the world's second largest oil shipping route exists, carrying oil from the Middle East to Northeast Asia. Offshore Vietnam has many oil fields to be exploited. Meanwhile, along the coast from north to south there are many shipping ports, oil ports; Every year the sea and coastal areas of Vietnam are subject to the effects of many big storms and changing weather conditions [1]. This is a constant threat to oil spills. Vietnam is an open ocean connecting the Pacific Ocean and the Indian Ocean, which is one of the major shipping lanes, with $70 \%$ of which are oil tankers [2],[3]. It has not yet been classified as a serious pollutant, but has also been warned of high pollution risks in the future, as industry is developing in coastal areas, plus exploration and mining activities. Oil and gas transportation in the region is increasing, while the area is often a dangerous disaster at sea [4],[5].

According to incomplete statistics, since 1989 there have been more than 100 oil spills from marine accidents, pouring into the sea from a few tens to hundreds of tons of oil. Total losses of economic and environmental caused by the incident can be up to tens of VND billion [6]. The cause of the oil spills are often caused by oil and gas exploitation, collision of tanker/tanker, broken oil pipelines, multiple bursts of fuel oil, or multiple decks on the platform, service ship incident; maritime activities; due to weather changes [4],[7]. In Vietnam, the risk of occurrence of oil spills is tending to increase, especially since 1993 to now, the average in the sea in Vietnam has three to four oil spills. Surveys show that most of the oil spills are caused by

Publised on July 16, 2018.

Phuoc Quy Phong Nguyen is with Ho Chi Minh city University of Transport, Ho Chi Minh city, Vietnam. collisions [8]. However, only three cases of oil spills were received, accounting for $8 \%$ of the oil spill incident; Six cases of administrative fines for the environment; $77 \%$ of the remaining cases do not, or lose compensation. Fig. 1 shows an oil spill accident in Vietnamese sea zone [9].

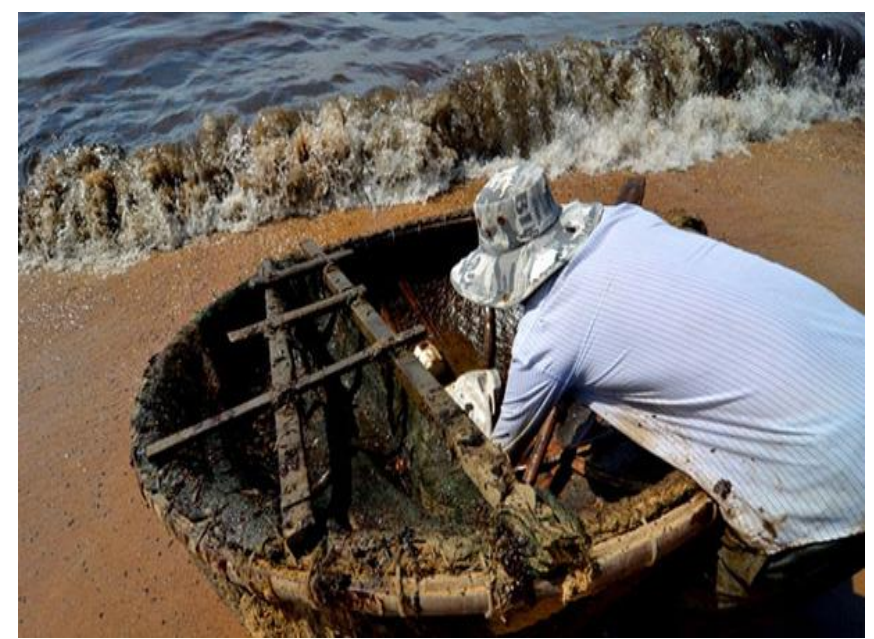

Fig. 1. An oil spill accident in Quy Nhon, Vietnam

The oil spill incident at sea has caused serious economic damage, polluting the marine environment, seriously affecting the ecosystem of mangroves, seagrasses, tidal areas, lagoons and coral reefs. ...; Spills also contain toxins that damage and can cause ecological degradation. Oil spills pollute the marine environment, seriously affecting ecosystems [10]. Especially ecosystems of mangroves, seagrasses, sandy tidal areas, lagoons and coral reefs. Oil pollution reduces the resilience, flexibility and resilience of ecosystems. Oil content in water is high, oil films reduce the oxygen exchange capacity between air and water, reducing oxygen in water, causing the balance of oxygen in the ecosystem to be upset [11]. In addition, spills of toxins damage the ecosystem, which can cause ecological degradation [12]. The oil contains many different components, which alter, destroy the structure of living cells, sometimes causing the whole population to die. Oil seeping into the sand and mud along the coast can affect a very long time [13]. There have been many cases where organisms die massively due to the effects of oil spills. It is also alarming that the oil spreading at sea and washed ashore for long periods of time without collection will reduce the number of organisms, causing damage to the fishing and aquaculture sectors [14]. Oil contaminates the water environment causing fish to die due to lack of dissolved oxygen [15]. The oil clinging to the soil, the stone embankment, the island coasts that make beauty look bad, causing bad smell to the revenue of the tourism industry is also severely damaged. Oil spills also affect the operation of fishing ports, ship building and repair facilities. As oil drift breaks down machinery, equipment for resource extraction 
and shipping [16]. Through the survey at Lach Bang fishing port, Tinh Gia district, Thanh Hoa province, where regular anchorage of thousands of fishing vessels from different regions. The state of pollution of water here due to the sludge of the ship "careless" discharge into a large black area [17]. Ten years ago, this estuary was home to a rich ecosystem of mangroves, but now almost all of the mangroves are dying out, leading to the erosion. brackish water is almost extinct [18]. This is also a continuous incident of oil pollution caused hundreds of hectares of aquaculture lost, so many households forced to quit.

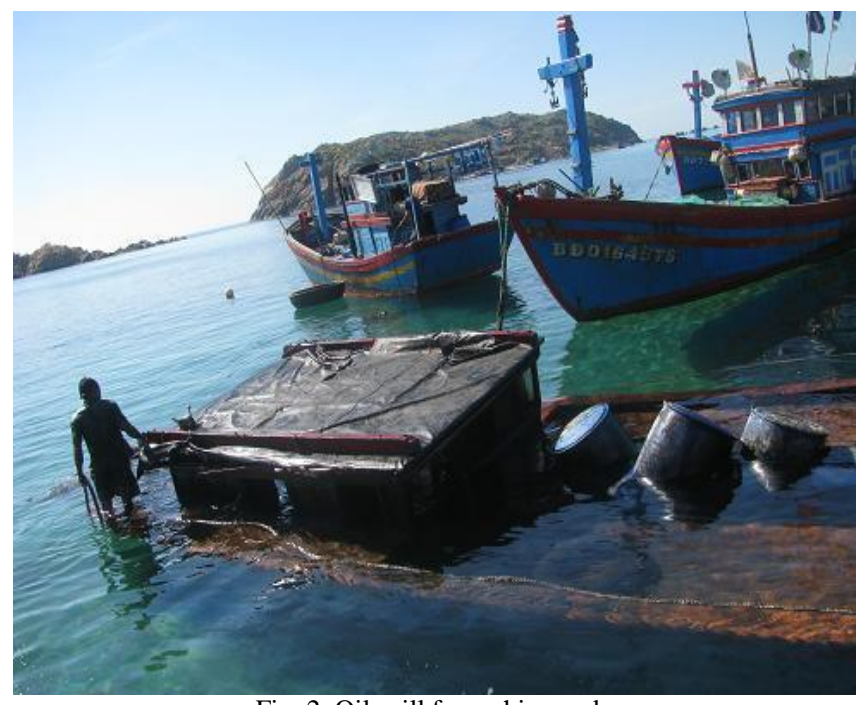

Fig. 2. Oil spill from shipwreck

Consequently, the oil spill incident can be considered as one of the types of breakdown that causes the greatest economic loss, in the type of human-induced environmental fault. Currently, the location of oil spills and overcome this problem in Vietnam still have many limitations, both legal basis and specialized equipment and technical means to overcome oil spills.

\section{SOME OIL SPILl INCIDENTS IN VIETNAM}

According to statistics from the Center for Petroleum Safety Research, more than 90 oil spills occurred in rivers and in coastal areas from 1987 to 2001 in Vietnam. In Ho Chi Minh City, from 1993 up to now, there have been over 8 oil spills with an estimated oil volume of 2,520 tons, causing damage of more than 7 million USD. Especially, in 2006, 2007 , in the coastal area of Vietnam, there were many "mysterious" oil spills. Especially, from January to June 2007 , there have been many oil spills in 20 coastal provinces from Bach Long Vi island to $\mathrm{Ca}$ Mau. These provinces have collected 1,720.9 tons of oil.

On 26/12/1992, Bach Ho Oilfield, soft duct from oil tanker to loading float spilled 300-700 tons of FO oil.

In 1994, the Neptune Aries crashed into the Cat Lai jetty in Ho Chi Minh City (a total of 1,864 tons of DO oil was spilled on the Petrolimex 01 ship of Vietnam in the Gulf of Tonkin - Vung Tau (in September 2001) spilled about 1,000 cubic meters of diesel oil into the coastal marine environment, then in the coastal area of Quang Ninh - Hai Phong three years later, the incident was about 50 tons DO oil and 150 tons FO oil, while we only handle about 65 tons, the remaining oil almost to the sea.
About 11h 20/03/2003, Hong Anh ship of Trong Nghia Co., carrying 600 tons of oil F.O from Cat Lai to Vung Tau, but when the Buoy No. 8 (Vung Tau) was sinking large waves. Oil started spreading to Can Gio area, HCMC.

In 2005, the Kasco Monrovia in Cat Lai - HCMC (518 tons of DO oil spilled). At 17:00 on 30/01/2007, thousands of tourists and people are bathing in

Cua Dai Beach - Hoi An (Quang Nam), Non Nuoc (Danang) panic run to shore, when a layer of black oil massively spilled into the land. The oil ridge extends nearly $20 \mathrm{~km}$ from the Danang sea to Quang Nam. An ecological disaster is showing up on the world's most beautiful coastline. By the end of February 2007, lupine oil appeared on the coast of 3 communes in Le Thuy district - Quang Binh. After more than 10 days, oil has spread over $60 \mathrm{~km}$ of sea coast from Nguy Thuy to Thanh Trach (Bo Trach district) with increasing density. Some nice beaches like Hai Ninh (Quang Ninh); Nhat Ninh, Bao Ninh, Quang Phu (Dong Hoi); Jumping Rock (Bo Trach) has been oiled in.

On April 19, 2007, oil spill occurred in the waters of Nha Trang and Ninh Thuan. In Khanh Hoa, oil spills to the beach in the center of Nha Trang city. In Ninh Thuan, the oil spills cover dozens of kilometers of coastline.

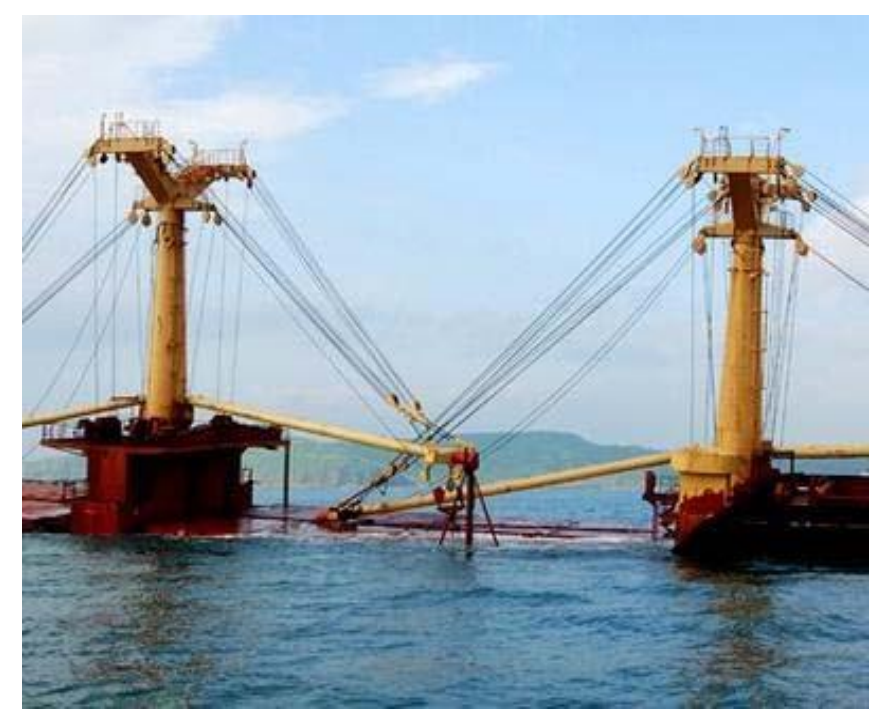

Fig. 3. New Oriental before sinking under the sea Phu Yen province

At the end of October 2007, the New Oriental shipping ship was disturbed and sunk in the waters of An Ninh Dong commune, Tuy An district, Phu Yen province. The oil spill out of the position of the sinking ship southwest to about $500 \mathrm{~m}$ wide with an estimated 25 ha.

On the evening of December 23rd, 2007, in the sea, about three nautical miles from Ba Lang An village, Binh Chau district, Binh Son district, Quang Ngai province, two cargo ships collided and over $170 \mathrm{~m} 3$ of diesel oil spilled into the sea. This is the accident between the two major cargo ships in the first time in the sea of Quang Ngai. However, there is no remedy to the $24 / 12$ afternoon.

About 22 hours on 02/03/2008 when the coordinates 102 degrees 9.7 minutes North, 107 degrees 47.5 minutes East of Binh Thuan sea, about 9 miles southeast of La Gi town, the German ship Tri BWEG carrying 1,700 tons of oil encountered waves, big wind, the ship was sunk. Due to heavy rains in several days, at 12 noon 16/10/2008, at the petroleum depot. On the Hai Van Pass (in the area of Hoa 
Hiep Bac Ward, Lien Chieu District, Da Nang), landslides occurred. Over $40 \mathrm{~m}$ of embankment protection basin \# 1 (containing about 3 million liters of A92 gasoline) and \# 2 tank (containing about 3 million liters of jet fuel) have been shattered. This unexpected incident caused the tanker tube line 2, from the supply to the storage facility, to break up, causing a large amount of oil (unspecified) to flow out, then spill into the sea.

Especially, in the years 2006 and 2007, there were some mysterious oil spills in the coastal provinces of Central Vietnam and South Vietnam, especially from January to June 2007 with many oil drift tracks along the coast. the sea of 20 provinces from Bach Long $\mathrm{Vi}$ island down to $\mathrm{Ca} \mathrm{Mau}$ cape and has collected 1720.9 tons of oil. By analyzing 26 photographs from the ALOS-PALSAR satellite between December 6, 2006 and April 23, 2007, the Department of Environmental Information and Research, Institute of Geography recognized the largest oil spill discovered on March 8, 2007 with a length of more than $50 \mathrm{~km}$ and a width of more than $1 \mathrm{~km}$. Based on marine oil spill and oil thickness, it is estimated that 21,620 - 51,400 tons of oil spilled on the sea. Over the past 20 years, about 10 large oil spills have been recorded each year, especially in 2012 with 12tons of oil spill, causing extensive pollution, affects the estuarine and coastal environment in Vietnam.

\section{CONSEQUENCES Of THE OIL SPILl}

\section{A. For the environment}

Changes in the physical and chemical nature of the water environment. Increases viscosity, reduces oxygen absorption into water, leading to severe damage to marine life, particularly coral reefs and organisms that are sensitive to hypoxia.

One ton of oil spills into the ocean, covering up to 12 square kilometers of water, forming a lining that separates water and air, altering the nature of the marine environment, impeding the exchange of oxygen and carbon dioxide with the atmosphere, changing the nature and coastal ecosystems. The waves hit about $10 \%$ of the oil. On the mainland, the oil contained many toxic chemicals, which damaged coastal land. Oil deposits settle to the bottom, which pollutes the sea bed sediment, affect regional climate, reduce evaporation of water, leading to reduced rainfall, poor marine resources.

\section{B. For creatures}

Many do not realize that all the animals in the ocean are photographed affected by the oil spill. Plankton, fish larvae, and bottom organisms are strongly influenced. Even seagrasses, oysters, oysters are also affected by the oil spill. Seeds permeate the seagull's feathers, reducing the protection of the feathers, thus making the birds vulnerable to abnormal temperature changes and reducing their surface water float. It also reduces the ability of birds to fly, making them more difficult to escape predators. When trying to prune feathers, birds often swallow oil to the abdomen, resulting in kidney damage, altered lung function, and stimulation of the digestive tract. These problems and the limited ability to absorb food cause dehydration and metabolic imbalance. Changes in hormone balance, including luteinizing protein, can also occur in some birds when exposed to oil. Most of the birds affected by the spill are dead unless there is human intervention. Oiled marine mammals are also affected similarly to birds. Oil covers the coat of the otters and seals, reducing metabolism and reducing body heat. When eating oily foods, animals will lose dehydration and reduce their ability to digest. Because oil floats on the water, it reduces light when entering the water, limiting the photosynthesis of marine plants and plankton. This reduces the number of individuals in the fauna and affects the food chain in the ecosystem. An oil spill could damage an entire food chain in the area.

\section{For economics, society and people}

Costly money to clean the contaminated environment was shown. For example, the oil spill in Alaska, (1989) cost \$ 2.5 billion for the cleaning process, and estimated total costs of $\$ 9.5$ billion. KASCO MONROVA vessel in Cat Lai - Ho Chi Minh City in 2005 (518 tons of DO oil spilled) compensated about 14.4 billion VND. When an oil spill occurs, there is a lot of damage and loss to both the state and the private sector.

In addition to the direct damage to property, there are long-term effects such as coastal tourism, aquaculture and fishing. Obstructing sea transport. Oil has a direct effect on the person through direct contact or inhalation of vapor resulting in nausea, headache, skin problems. They also cause some diseases such as cancer, lung disease, hormonal disruption. Serious economic damage to the people. The decline in fish catch, more fish caught on sale in the market, consumers do not dare eat fish shrimp smell gasoline so people watch the fish. Reduced productivity of aquaculture. The oil spill danger is forcing the clam farmers to face the risk of losing thousands of billions if the clam is killed by oil pollution.

\section{VIETNAMESE GOVERNMENT POLICY}

This Regulation prescribes the contents of activities of preparing, organizing the response to, overcoming and dealing with the consequences of oil spills and the responsibilities of organizations and individuals for oil spill incidents in their territories and regions. Vietnamese sea.

Oil spill response activities must ensure the principle of actively preventing and taking initiative in making plans, investing in equipment and contractual options in order to respond to incidents; To organize the reception and processing of information in a timely manner, prioritizing the provision of information for the response and promptly reporting to competent authorities when they exceed their coping capability; mobilize all resources to improve the effectiveness of preparation and response, prioritize the rescue of victims and protect the environment. Based on the level of the oil spill incident, the organization and implementation of the response shall be conducted at three levels: the grassroots, the regional and the national level.

Oil spills are broken down into three levels ranging from small, medium to large. A minor incident was an oil spill of less than 20 tons of oil. Average incident is an oil spill incident of 20 to 500 tons. Major incidents are oil spills of more than 500 tons.

The National Committee for Search and Rescue shall assume the prime responsibility for, and coordinate with the concerned agencies in, formulating and submitting to the 
Prime Minister for approval a national plan on response to oil spills. Provincial People's Committees at risk of oil spills from the average level must prepare their local oil spill response plans.

National Committee for Search and Rescue appraisal and approval. Local ports, establishments and projects shall have to elaborate oil spill incident response plans and submit them to provincial-level People's Committees for consideration and approval. In addition, the Regulation also provides for the responsibility for the preparation of oil spill incident response plans of offshore oil and gas businesses, offshore oil and gas facilities and oil spill response centers., tankers of a gross tonnage of 150 tons or more and other ships of a tonnage of 400 tons or more, Vietnamese oil tankers of a gross tonnage of 150 tons or more. To receive information, according to the provisions of this Regulation, organizations and individuals that cause oil spill incidents shall have to report to the national liaison office for oil spill incident at sea; The nearest port; Regional Oil Spill Response Center;

Regional Center for Maritime Search and Rescue Coordination; Vietnamese coastal information stations for forwarding information on the agencies assuming the prime responsibility for the response or the rescue and / or rescue agencies; Resource base and environment; Nearest local authority; Permanent search and rescue agencies of the concerned ministries, branches and localities. Apart from these focal points, when detecting incidents or detecting incidents, information may be sent to coastal information stations, district-level People's Committees, naval units, border guards, Waterway traffic police to process or forward information to the agency in charge of the response. Response to oil spill incident at the grassroots level, Regulations on marine response, application at the facility, project, in the port area. At the same time, the Regulation also provides specific regional and national level oil spill response.

On overcoming and dealing with consequences of oil spills, the Regulation on investigation and identification of causes of oil spills; Resolving the consequences of oil spills.

\section{CONCLUSION}

In order to prevent, respond to and deal well with oil spills in the sea and in the near future, Vietnam should soon develop oil spill warning maps. Vietnam needs to develop oil spill sensitivity maps, especially the model for calculating oil spill response to different oil spill scenarios; Raise awareness of the community in this area.

In addition, the relevant agencies should soon review and publish technical guidelines such as: guiding methods, procedures for investigating and evaluating oil spills; Guide to environmental rehabilitation of oil spill area.

Localities need to develop plans and implement practical activities such as organizing on-the-job human resources training, in which practice and skill training are essential; To build and develop environmental incident response stations.

Environmental incident response stations are not only capable of responding effectively to problems, but more importantly the experts of the stations will help enterprises to identify potential risks in time. To exclude, do not let the incident happen.
These stations also help to better manage the environmental protection, especially those related to the exploitation, processing, transportation, trading and storage of oil and chemicals. Responding to oil spills, chemical incidents in localities.

\section{REFERENCES}

[1] N. U. Sekhar, "Integrated coastal zone management in Vietnam: Present potentials and future challenges," Ocean Coast. Manag., vol. 48, no. 9-10, pp. 813-827, 2005.

[2] P. H. Hoang, A. T. Hoang, N. H. Chung, L. Q. Dien, X. P. Nguyen, and X. D. Pham, "The efficient lignocellulose-based sorbent for oil spill treatment from polyurethane and agricultural residue of Vietnam," Energy Sources, Part A Recover. Util. Environ. Eff., vol. 40, no. 3, pp. 312-319, 2018.

[3] S. Musk, "Trends in oil spills from tankers and ITOPF non-tanker attended incidents," in Proceedings of the Thirty-fifth AMOP Technical Seminar on Environmental Contamination and Response. Environment Canada, Vancouver, British Columbia, Canada, 2012, pp. $775-797$.

[4] A. T. Hoang, V. V Pham, and D. N. Nguyen, "A report of oil spill recovery technologies," Int. J. Appl. Eng. Res., vol. 13, no. 7, pp. 4915-4928, 2018

[5] D. Ngo, J. L. Gibbons, G. Scire, and D. Le, "Mental health needs in Vietnamese American communities affected by the gulf oil spill,' Psychology, vol. 5, no. 2, p. 109, 2014.

[6] "No Title." [Online]. Available: http://tapchimoitruong.vn/pages/article.aspx?item=Sự-cố-tràn-dầu-vàkhả-năng-ứng-dụng-công-nghệ-viễn-thám,-GIS-trong-giám-sát-tạiViệt-Nam-46786. [Accessed: 15-Feb-2018].

[7] A. T. Hoang, X. L. Bui, and X. D. Pham, "A novel investigation of oil and heavy metal adsorption capacity from as-fabricated adsorbent based on agricultural by-product and porous polymer," Energy Sources, Part A Recover. Util. Environ. Eff., vol. 40, no. 8, pp. 929939, 2018.

[8] "No Title." [Online]. Available: https://ccbvmt.danang.gov.vn/index.php?option=com_content\&view= article\&id=397:nhung-hau-qua-o-nhiem-moi-truong-bien-do-su-cotran-dau-\&catid=75:kiem-soat-o-nhiem\&Itemid=101. [Accessed: 25Mar-2018].

[9] "No Title." [Online]. Available: http://vietnamnews.vn/environment/241846/unidentified-oil-spill-hitsquy-nhon-port.html\#oXB4Dj7VrovC64hU.97. [Accessed: 25-Mar2018].

[10] "No Title." [Online]. Available: http://www.nhandan.com.vn/xahoi/item/34541102-phong-ngua-ungpho-su-co-tran-dau-tren-bien.html. [Accessed: 16-Jan-2018].

[11] H. Le Minh and D. N. Dinh, "Vietnam 'Oil Spill Detection and Classification by ALOS PALSAR at Vietnam East Sea' 7th FIG Regional Conference Spatial Data Serving People: Land Governance and the Environment-Building the Capacity Hanoi." Vietnam, 2009.

[12] M. J. Valencia, "Vietnam: Fisheries and navigation policies and issues," 1990

[13] A. T. Hoang et al., "An absorption capacity investigation of new absorbent based on polyurethane foams and rice straw for oil spill cleanup," Pet. Sci. Technol., pp. 1-10, 2018.

[14] S. R. Shadizadeh, A. Khodashenas, S. M. Abtahi, and E. Roayaei, "Experimental investigation of oil spill cleanup using cholan as a natural oil absorber," Energy Sources, Part A Recover. Util. Environ. Eff., vol. 36, no. 9, pp. 982-992, 2014.

[15] N. Nasuchon, "Coastal management and community management in Malaysia, Vietnam, Cambodia and Thailand, with a case study of Thai fisheries management," Div. Ocean Aff. Law Sea, Off. Leg. Aff. United Nations, New York, 2009.

[16] M. J. Wilson et al., "A targeted health risk assessment following the Deepwater Horizon oil spill: polycyclic aromatic hydrocarbon exposure in Vietnamese-American shrimp consumers," Environ. Health Perspect., vol. 123, no. 2, p. 152, 2015.

[17] X.-Q. Le, V.-H. Vu, L. Hens, and B. Van Heur, "Stakeholder perceptions and involvement in the implementation of EMS in ports in Vietnam and Cambodia," J. Clean. Prod., vol. 64, pp. 173-193, 2014.

[18] N. Singkran, "Classifying risk zones by the impacts of oil spills in the coastal waters of Thailand," Mar. Pollut. Bull., vol. 70, no. 1-2, pp. 34-43, 2013. 